https://doi.org/10.32686/1812-5220-2021-18-3-8-9

ISSN $1812-5220$

(О) Проблемы анализа риска, 2021

\section{Возможность управления рисками ЧС и катастроф}

Башкин В.Н., член редколлегии
Для цитирования: Башкин В.Н. Возможность управления рисками ЧС и катастроф // Проблемы анализа риска. Т. 18. 2021. № 3. С. 8-9, https://doi.org/10.32686/1812-5220-2021-18-3-8-9

\title{
The Ability to Manage the Risks of Emergencies and Disasters
}

Vladimir N. Bashkin, Associate Editor
For citation: Bashkin V. N. The ability to manage the risks of emergencies and disasters // Issues of Risk Analysis. Vol. 18. 2021. No. 3. P. 8-9, https://doi.org/10.32686/1812-5220-2021-18-3-8-9

По своей сути, решение задач по возможности управления рисками чрезвычайных ситуаций и природно-техногенных катастроф, начиная с их постановки, непременно должно быть объектно-ориентированным, а именно быть направленным на предотвращение потенциального ЧС или катастрофы. При этом, отвечая на возникающий вопрос: «А можно ли вообще предотвращать катастрофы?», прежде всего нужно подчеркнуть, что это необходимо, хотя не во всех случаях возможно. Наиболее распространенными ранее способами предупреждения потенциального развития ЧС и катастроф были, в частности, увеличение запаса прочности технических решений, включающих возможные изменения природных условий, вплоть до природных катастроф, удаление работы технологических процессов от их точек бифуркации, строительство дополнительных объектов здравоохранения на случай развития инфекционных заболеваний или даже пандемий и ряд других, получивших распространение в предшествующие годы и влекущих большой перерасход финансовых и материальных ресурсов. Хотя такие же методы могут использоваться и реально используются порой и сейчас, но они влекут за собой большие дополнительные затраты. В то же время можно работать и при угрозе возникновения ЧС или даже катастрофы, поскольку их развитие требует определенного времени (например, изменения климата $-2-3$ десятилетия, для рекультивации нарушенных и загрязненных земель это один-два сезона, для развития инфекционных болезней - несколько месяцев или даже недель - дней, а для газотурбинного двигателя - около 100 мс). Это время обычно называют горизонтом событий. В таком случае реакция на возникающую ситуацию должна последовать не позднее, чем истечет половина отведенного в конкретной ситуации времени, а все управленческие, финансовые, материальные и технологические решения обязаны определяться продолжительностью переходных процессов данного конкретного ЧС или катастрофы, независимо от ее природы. И самое главное, необходимы именно технологическая оценка горизонта событий и ориентация на ее величину с использованием всех имеющихся в распоряжении методов, от управленческих до финансовых. Такой подход позволяет рассматривать и оценивать (качественно и количественно) вероятность управления рисками ЧС и катастроф при оптимальном расходовании ресурсов. 
Рассмотрим конкретные примеры решения вопросов управления чрезвычайными ситуациями и катастрофами.

Известно, что изменение климата и природные катастрофы, вызванные гидрологическими, метеорологическими, климатическими причинами, оказывают значительное и все возрастающее прямое и косвенное воздействие на здоровье человека, приводя к повышенному риску смерти, болезней и травм. Из-за своей обширной территории, сложной географической и экологической среды и сильно различающихся климатических условий Россия является одной из стран, которые страдают от частых климатических и погодных катаклизмов. Для управления или хотя бы возможности управления этими явлениями необходимы сведения о погодных экстремумах, в частности, в России в 2010-2020 гг. - наводнениях, тайфунах, ледяном дожде, засухах и об их воздействии на здоровье и жизнедеятельность населения. Показано, что, хотя большинства из опасных гидрометеорологических событий невозможно избежать полностью, многие последствия для здоровья потенциально могут быть предотвращены с помощью систем раннего предупреждения и мер по обеспечению готовности общественного здравоохранения и реагированию на них, путем создания устойчивых к изменению климата систем здравоохранения и других управленческих структур.

Так, имеются возможности оценить различные направления работ по смягчению последствий коронавирусных инфекций и тех крупномасштабных угроз, связанных с возникновением пандемий. Управление такими угрозами требует именно управленческих решений на уровне органов государственной власти и их решительных действий по смягчению последствий массовых заболеваний. Обобщены возможные направления работ по снижению риска коронавирусных инфекций.

Также нужно понимать и оценивать сами риски глобального изменения климата, а также вопросы защиты (адаптации) населения, территории и экономики России в связи с этими изменениями. Эта проблема носит глобальный характер. Так, страховые компании фиксируют устойчивый рост количества природных катастроф и неблагоприятных событий - наводнений, ураганов, тепловых волн, града, засух, природных пожаров. Общий нанесенный ими ущерб с 1980-х гг. превышает 5 трлн долл.

Проведенная оценка риска природопользования для стран Европейского союза показала наличие двух главных критериев - природной опасности и защищенности от стихийных бедствий. Природная опасность складывается из природных процессов различного ге- незиса - литосферных, гидросферных, атмосферных и биосферных, которые, согласно официальным данным, считаются опасными в рамках всего государства, а также из защищенности от стихийных бедствий и катастроф на государственном уровне. Поэтому при оценках риска природопользования, последующем его анализе и управлении ЧС природного и природнотехногенного характера не следует опираться только на показатели уровня экономического развития в странах, например ВВП, а также на установленные, пусть и на международном уровне, экологические стандарты, такие как ПДК, ПДВ вредных веществ в почвах, растениях, водных объектах, атмосферном воздухе и т. п. Учет при оценках риска природопользования прямых показателей, ущерба от прошлых событий также страдает рядом недостатков. Необходим дифференцированный подход.

И в конечном итоге процесс управления рисками устойчивости представляет собой бизнес-процесс, поддерживающий цели компании в области устойчивости и направленный на приведение устойчивости в соответствие с управлением рисками на основе использования принципов корпоративного управления рисками. Связанные с этим риски определяются практикой бизнеса компании, его стратегией и сектором экономики, в котором она работает. Такие подходы могут включать в себя риски экологические (климат, ресурсы, загрязнение), социальные (люди и коммуникации, продукция и сервисы, внешние и внутренние акционеры) и управленческие (корпоративное управление, бизнес-этика и поведение). Компании, находящиеся в стадии «устойчивого развития», используют корпоративный подход к рискам и увязывают их с общими стратегическими целями. В процессе выявления указанных сопряженных рисков можно придерживаться разных подходов, в частности: ведения реестра рисков, включая ESGриски, либо обсуждения различных перспектив устойчивости компании и связанных с этим рисков с топменеджментом и акционерами, или проведения сортировки рисков, имеющих отношение к стратегическим, операционным и внешним. При этом оценка устойчивости должна быть более широкой и многоаспектной, должны учитываться потенциальные последствия для компании, ее репутации и долговечности.

Таким образом, эти и другие темы, рассмотренные в данном номере журнала, позволяют ответить на вопрос о возможности оценки (качественной и количественной) вероятности управления рисками ЧС и катастроф с тем, чтобы выбирать наиболее оптимальные решения, экономя время и материальные ресурсы. 